\title{
A CASE OF THE DEAF WHO WAS GIVEN THE EARLY SPEECH THERAPY BY HEARING AID AND LIP READING
}

\author{
By \\ SANETOMr EGUCHI and Hiziri OGATA \\ From the Department of Oto-rhino-laryngology, Medical Faculty, \\ University of Nagasaki (Director: Prof. T. Goto)
}

The authors observed on a case of a 21 year old male, who was found deaf when he was 3 year of age and was given a early speech therapy with hearing aid and lip reading.

1) By the pure tone audiometry his air conduction hearing was $81 \mathrm{db}$ in the left ear and was $86 \mathrm{db}$ in the right ear. Bone conduction were all scaled out.

2) The results of articulation test in pronou- nciation were $84.3 \%$ and lip reading ability were $46 \%$ in case of help of the hearing aid and lip reading method, these results show twice as good percent as the deaf who was given the lip reading training only.

3) From these observations, the authors believe that the hearing aid is nessessary in the early speech therapy upon the congenital deaf child, regardless of the type and degree of the deafness.

\section{補聴器を併用した早期言語治療の 成果を示した龍啞者の一例}

\author{
長崎大学医学部耳鼻咽㬋科学教室（主任: 後藤敏郎教授)

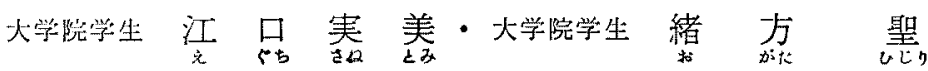

\section{舶言}

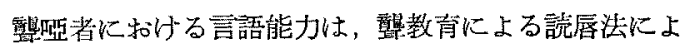
つて習得されているが，その会話能力については末だ多 く問題点があり，これが研究は今後の大きな課題となつ ている。近年，我国に沶いて子，医学エレクトロニクス

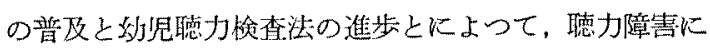

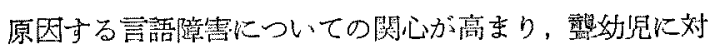
する言語教育の再梌討が必要となりつつある現沿であ る.

著者らは，最近，補㫩器を灌用しながら普通学校へ通 学して義枒教育を受けた高度難聴の青年についての臨床 観察を行つたところ，興味ある成續を得たので報告し， 諸家の御批判を乞う次第である。

$$
\text { 症例 }
$$

患者：21才，男子

主訴：難德及び言望障害

現症歴：満 3 才になつても全く喋らないので，聴力
障害があるのではないかと考觉るようになり，地方の耳 鼻咽唉科專門医涂察を气らたが，幼小であるから，わ からないと云われた，そのまま放嘼していたが，満 5 才

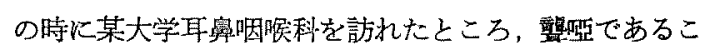
とを知らされ，補聴器を淩用するよらに指示された。 そ れ以来，家庭に淤いて本を読んで，口唇を見させながら 言葉を教えた.小学校入学時㣚学学校へ入学させるべき か否かについて迷つたが，普通学校へ入学させることに した. 勿論, 当時は言語能力は非常に少なかつたが, 次 第に日常の身の廻りの物の名前から他人との応対に必要 な言葉などを理解し，話すようになり，中学を卒業する 頃は会話には不自由はきたさない程度となつた，在学中 の学様成績は言うまでもなく下位であつた．卒業後は家 業を手伝つているが，他の従業員との間にるなん5日常 生活に不自由をきたしていない。

家族歴：両親は近親結婚（従兄弟）であつて，患者 は男 4 人, 女 3 人の子供の5ちの 5 番目である. 親族に 


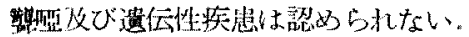

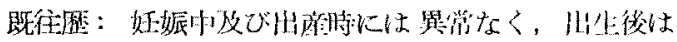

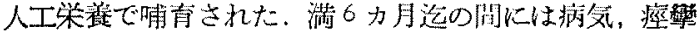
発作等はなからた。满 2 才の時に肺炎で約 l週間高䓡が 続いたことがあり，又，2m 位の高所から転落して頭を 打つたことがある，以後，今日まで，風邪に罪る程度で あり，ストマイ使用，下㥔の乱用等は認めていない，満

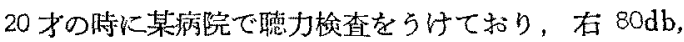
左 $82,5 \mathrm{db}$ であると云われている。

心身の発育経過：首の座りは6カ月頃，起立できる ようになりたのが満 1 才半頃，歩行開始が 2 才頃であ り，身体の発育はやや遅れていたと考宎られる。知能の 発達は正常であつたょうである。言語発達については，

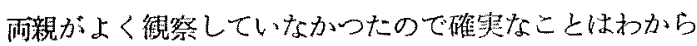
ないが，輀2才の頃は何か㗱つていたよらであると言つ ている.

現在の状態（家人の見た）：聴力は非常に项 々，大声でやつと鳃えているようである。言語は 日常生活に必要な言藮は大件言うことができる が, 言語理解能力は中学 1 年程度であると思われ る、性格は非常に报となしく，偏食，僻，等な

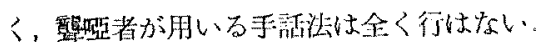

\section{检查成綪：}

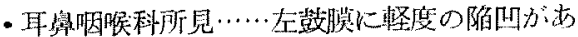
万他には器質的病変奴い。

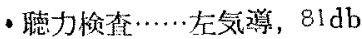
右気憎, $86 \mathrm{db}$

骨道衈力小两耳共汇测定不能（図1).

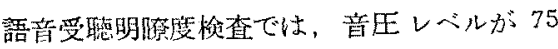
$\mathrm{db}$ より受㯖可能であり，左耳では 80〜95db でわずが5\%となり，100dbでは $42 \%$ と なる。右耳では，80 90dbでは左耳と同様 5\%であるが，90〜100db の間では 95db に

牤いて 42\%をピークとした山型を示している（図 2).

=X線検查…...Schüller 氏法，Stenvers 氏法によつ て撮影を行った。病的所見は認められない。

・語音発語明嘹度榆查……清音，濁音，塮音よりなる 83 語の㭘查語音表を読ま中，これを録音し，その 再生音声を 5 人の聴力正常な检者に聴かせて，明膫 度算出を行つた，成績は表1に示寸ごとくである。

これらの検查で誤つて聴取された語音と，誤つた発音 :を比校検訶してみると表 2 のらになる，各検者を
图 1 - Air Conduction Audiogram

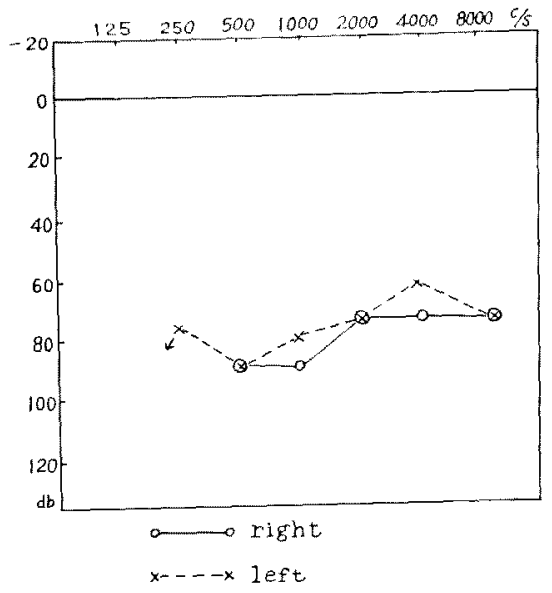

Bone Conduction All Scale Out

図 2 Speech Audiogram

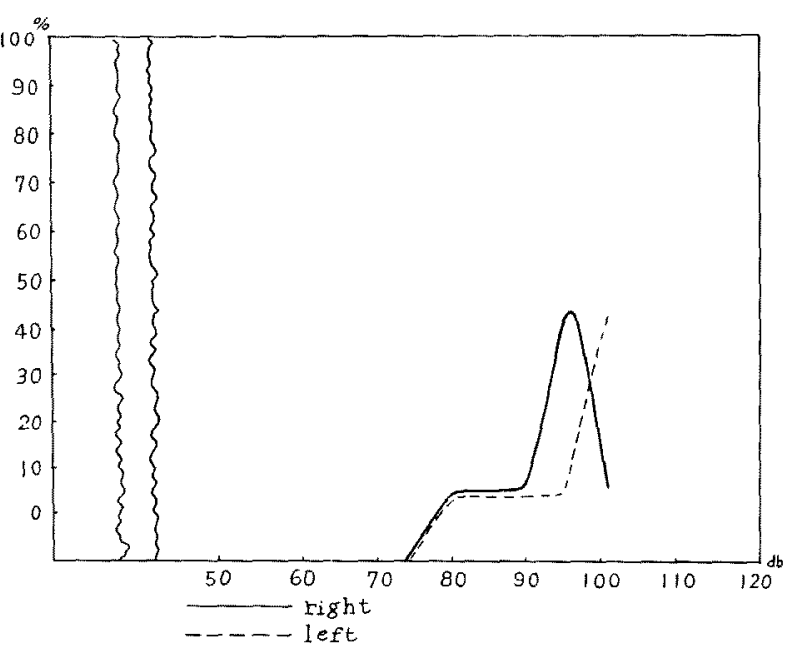

\begin{tabular}{|c|c|}
\hline 険 渚 & 明膫度 $(\%)$ \\
\hline A & 84.3 \\
\hline B & 85.3 \\
\hline C & 84.3 \\
\hline $\mathrm{D}$ & 85.3 \\
\hline $\mathrm{E}$ & 80.7 \\
\hline 平均 & 84.3 \\
\hline
\end{tabular}


表 $\quad 2$

\begin{tabular}{|c|c|c|c|c|c|}
\hline 檢查語 & A & B & $\mathrm{C}$ & $\mathrm{D}$ & $\mathrm{E}$ \\
\hline$=$ & & & & & $\vec{c}$ \\
\hline さ & & & & & Lњ \\
\hline L & & & & & Lゅ \\
\hline 5 & & & & & 乙ゅ \\
\hline せ & & & & & Lゃ \\
\hline z & & & Lょ & & \\
\hline b & & & & & b5 \\
\hline$D$ & & & & & た \\
\hline 5 & & & $\zeta$ & & \\
\hline 5 & $t_{\alpha}$ & & & & \\
\hline$b$ & $k$ & & & & \\
\hline る & 12 & & & & \\
\hline れ & $\sqrt{12}$ & & & & \\
\hline ろ & $\infty$ & & & & \\
\hline$わ$ & ま & & & & \\
\hline$\rightleftarrows$ & びゃ & $U_{p}$ & $\tau_{p}$ & & $p$ \\
\hline $\mathcal{L}^{*}$ & & $L_{\Phi}$ & & & \\
\hline वें & $l_{w}$ & $\iota_{\omega}$ & & & \\
\hline మే & $\dot{L}_{\lambda}$ & $\mathcal{L} \dot{\lambda}$ & & & $\dot{L}$ \\
\hline$\ddot{z}$ & $\breve{L}$ & $\iota_{ょ}$ & & & \\
\hline$た$ & & $t_{s}$ & & & \\
\hline で & & & & & ぜ \\
\hline$\ddot{\varepsilon}$ & & & & & $z$ \\
\hline ば & ぱ & ぱ & & & ば \\
\hline び & び & び & & & $\ddot{2}$ \\
\hline 5 & & $5:$ & む & & む \\
\hline べ & & $\ddot{0}$ & め & & め \\
\hline $\mathscr{E}^{*}$ & & ぼ & b & & $b$ \\
\hline$\eta p$ & & & p & & \\
\hline$\eta$ & & & 雨 & & \\
\hline よょ & & & 上 & & \\
\hline びゃ & & & & $p$ & \\
\hline$L_{p}$ & & & $p$ & & \\
\hline$U_{\oplus}$ & & & $\Phi$ & & \\
\hline$V_{5}$ & & & L & & \\
\hline
\end{tabular}

A. B. C. D. E.として，それぞれが聴取した通りに記 载した。

・読話能力検查……語音受聴明瞭度検查に用いる検查 用語を，患者との距離を $1 \mathrm{~m}$ に保ち，被検者の耳 もとでできるだけ 60phon になるようにして発音し て, 次の四つの状件で検查を行つた。

イ）読辰洗之補㯖器の搠用
ロ）読唇法のみ, 補聰器なし

八）補聴器のみ，口辰をかくす

）読唇法，補聴器，兩者とも火行なわず

以上の検查結果を 50 音順に整理して，これを険査語 音裴と比较表示すると次のようである。

(○検查語音表

あかさたなはまやらわだばがじ

いきしちにひみり す

らくすつ らむ㠴る

京けてね めれで

おこそとのほする どご

○検査結果及び読話能力(丸印は正しく德取した語音)

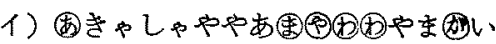

(4)いきぎいい( (1) 5

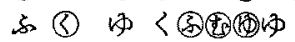

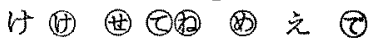

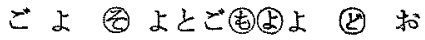

$(46 \%)$

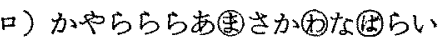

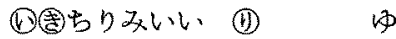

くらくゆ中类方中

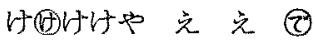

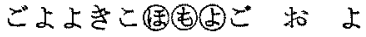

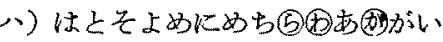

ろみりやきびち め ね

わさむち み占そそ

ら上めけ出 ら ね

よめけらこけけきにの泞

）めにたいとるむるひろなだたに

かいらめるらりょうつ

よさらい权によ

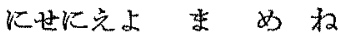

さらよよ构さららひと よ

\section{考按}

難聴を発見された奻䧋について，これが対策をいかた すべきかは非常に重要な問題であるが，今日の 段階で は，多くの場合，適切な対策がなされることなくして放 置され，学令期保迲すると瑟学校一入学させているのが 現状である。しかし，最近に至り，早期に聴力障害を発 見し，早期汇適切な対策がなされるなら代普通教育を受 けることができる可能性のあることが注目されてきてお゙ り，又，普通教育に成功した症例の報告が我国において も散見されるようになってきている。しかるに，かかる 場合の德力障害を医学的に治療治癒せしめることは非常 に困難であり，特に神経性難聴に拉いては，先ず希及は ないと言わざるを得ない，故に難㯖奻児を発見した場 合，唯，医学的治療のみを固持することなく，早期言語 治療 (Early Speech Therapy) を行うことが重要なの 
である、かかる害味において，本証例について考按を加 えることは意綿が深いと考える。

難聴発見時期について

乳幼坚期に特ける聴力障害の有無を早期に知り，早期 に言語治療を行らことは重要な問題であるが，一般には 殆んど注意が払われていない。

正常児の㯖覚については，新生胃では既に生後30分

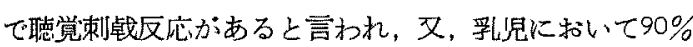
が音に反応すると言われているが，その程度については 成骎すると同時に次第に閵值が下降してくると報告され ている、しかし，一般には医師の注意をよく聞く，注意 深い母親ならば満1才前後には聴覚の有無について筑付 くことができるのである、私らの例にも生後6力月の頃 から聴力障害を発見した母親もあつた。

我々の Speech and Hearing Clinic 訪机てきた症 例について観ても，平均して生後1年6力月頃に発見され たものが多く、稀に満1才前に発見されたものもある。

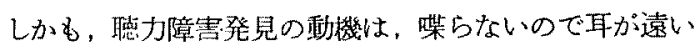
のであろらと考えるよらになつたものが殆んどである。

一方, 言語は feed back process 飞よつて谳語より 摸做語を経て完成されると目われているが，恥力障畫を 有していると摸做語への進屡が不可能となり㕵となる。

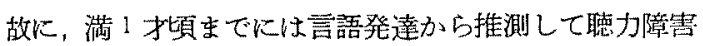
を知ることは困難である。このことは掺言すると，枼ら ないから耳が遠いと気村いた時は，すでに摸倣語の存在 がないことであり，この時期迄には迤くとも聴力障書を 確定して，言語治療を行らべきであると考えられる。

本症例では，满了才になつても全く㖼らないので衈力 障害を疑うようになつており，それまでに音に対する反

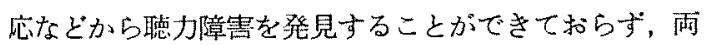
親の注意の少なさを物語つている。即ら本症では满了才 になる迄の間に摸倣語を発していないことは明らかで， 発見の時期としては非常に遅い，又，塄力障害発見の時 に相談された当時の専阴医が，好少であるとの理由で㯖 力檢查ができなく，よくわからないと答をているのる， 炤和19〜20年頃であつたから当然であつたか子知れな

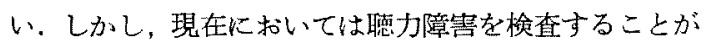
できるので，早期に発見与ることができるよらになつて きている。

一方，摸做語を経て完成される言語は满」才半頃より その数も急速に增加し，大体，满了才頃には完成されて くる，故に早期に難觙を発見して，遅くともこの时期に は言語治療孝開始しなけれはなならない、本症例では，满

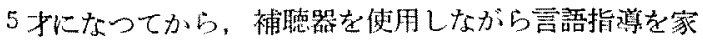

这に叔いて初めているが，時期的にやや幄すきた感じで

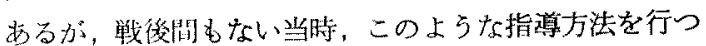
たのは雨親の英断上言わさるるを得ない。

票語所見について

翻罗の語音発語明瞭度については，読唇法のみによる 教育によると 11 才頃に 40〜50\%となり, それ以上は上 琏しないと云われている，本症例では84.3\%を示し，読 唇法のみによるものより明瞭度が高いここれは補噹器を 使用することにより，平均聴損が $81 \mathrm{db}$ という值にもか かわらず，諳唇法による視覚を通しての言語習得の上に 不完全ながら feed back process が成立し, 言語の 明䝶性に関与する dynamic な構至渾動を助けていると

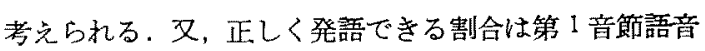
が最も良く，次いで第 2 音節語音，第3 音節語音の順で あるとされているが，本症例では，このよらな傾向がな く、むしろ，濁音の発語が不明膫であつた。

読話能力については，読唇法の教育によつては，12才 㥧に 20〜25\%となるが，聴力正常者では 10\%以下であ るとされている，しかるに，本例に和いて検査した成績 では，補聴器を装用しながら読原㳊を用いると46\%と高 い值を示しており，補聴器を使用しないで読唇法のみに よると $22 \%$ である。後者は，現在まで行なかれている 読履法による琶教育によつて得られる能力と一致した值 である，更に，日唇を見せないで，補聴器の的力のみに よるものでは6\%しか正しく聴取でき才゙，又，補聴器る 体用世ず，読唇法も用いない場合では，全く㶿取できて いない、この結果から云える重要なことは，高度難聴罗 を放置しておいて，ないら対策を加党ないならば完全な

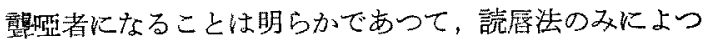
て言語指顛を行うならば，改献に示されているごとく 20〜 25\%以上の読話能力を得ることは困難であるが， 早期に難聴を発見して，早期に補聴器饻用しながら口 辰法を搠用して言語治療を行うならば，本症例に示され たように約 $50 \%$ ，あるいはそれ以上の読話能力が 獲得 されると確信する。

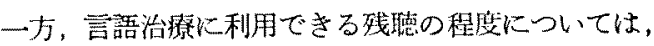
$75 \mathrm{db}$ か限界であると言われて扣り，又，83db以上を 完全酔であるとするならば，本症例の残存㯖力は完全锤 に近く，言語治療に利用できる限界を越えているが，か かる高度の先天性の㯖力障害児に扎いても言語治療にお ける補聴器の效果が無視できないことを証明していると 考えられ，この点から，難聴の種類及び程度に対する補 聴効果への一般的な適応の問題とは別個に聴力障害幼児 
の早期言語治療には䋠㯖器の婊用は必要なものであるこ とが推測された。

\section{結語}

満 3 才の時に 高度の 聴力障害の 存在することを発見 し, 满 5 才の時から補聴器を併用して早期の Speech Therapy 袁受け，言語能力は穜しく向上し，普通教有 を受けた 21 才の青年について聴力及び言語の 観察を行 つた。の結果，次の結論を得ることができた．

1）語音発語明瞭度は $84,3 \%$ を示し，読唇法の及の場 合の約 2 倍の明膫度を示した。

2）読話能力は, 補聴器の装用之読唇法の併用の場合 が最も良く46\%を示した。この值は読唇法のみによる 場合の能力の䄪 2 倍の值である.

3）先天性の高度の難聴胃の早期言語治療には，補聴 器は難聴の種類，程度に関係なく用いたが良いことを示 した例であった。

\section{文献}

1) Stanley Zerlin: A New Approach to Hearing Aid Selection, J.S.H.R. 370, $1962 . \quad$ 2) Fowler E.P.: Test for determining hearing impairment and ability. J.A.M.A. Oct. 18, 678 683, 1952.

Levin and others: Voice and Speech Disorders, Thomas, 1962.44)武山他：先天性万う児の語音の 発語と Lipreading に関寸る锥察，耳喉科，27：356, 1955.5) 高木: Early Hearing Training 9 可能 性について, 耳诶科，32:223，1960. 6) Jerger, J., Carhart, R. \& Dirks, D.: J. Speech \& Hearing Research, 4, 137, 1961. $\quad$ 7) Travis and others: Handbook of Speech Pothology, Appleton-CenturyCrofts, $1957 . \quad 8)$ R. Ewing and A.W.G. Ewing:
Speech and the Deaf Child. Manchester University press, 1954.99$)$ Huizing H.C. and D, Pollack:

Effect of limited hearing on the development of speech in children under three years of age. Pediatrics, 8, 53 $\sim 59,1951$.

10) Berry and Eisenson,: Speech Disorders, Appleton-Century-Crofts, 1956. 11) Beckmann, G.: Das hörgestörte Kind, Arch, Ohr.-, Nas.- Kehlk, Heilk. 180. Bd., I. Heft, 1962.

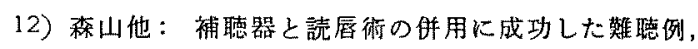

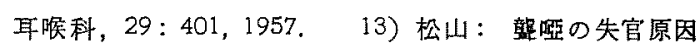
とついて，日耳奥，59：289。1956。14）村島：ある

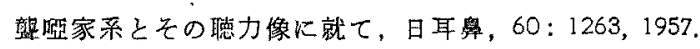
15)内田他：解児の会話能力，日耳奥，62：1904, 1959.116）武山他：正常幼児の語音の発莘之後天性

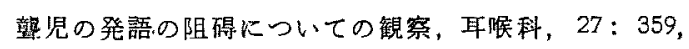
1955.17）高木他：煭児の残存聴力及びその利用に ついて, 耳㮢科，35：41，1963。18) 中鄉：新退児

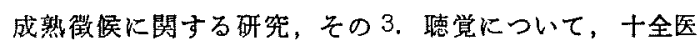
学, $48: 1930,1943.19$ ) 永浜：補聴器の轞床, 耳 薙科，29:187、1957。20) 永浜：補聴耳の語音検查 法，日耳帛，60：888，1957。21）梅垣：難㯖患者の 言語による明瞭度之音龍歪の检討，第1 編, 日耳， $57: 1100$ ，1954。第 2 絀，日耳奥，58:1，1955。22) 森本，志井田：聴力检查の手引，医学䒹院。23) Illinois Annual School for Mothers of Deaf ChiIdren: If you have a Deaf Child, $1959 . \quad 24) H$. Davis \& S.R. Silverman: Hearing and Deafness, Holt, Rinehart and Winston.

（原㚛到着二昭租 38.6 .21 日） 